\title{
PHYTOCONSTITUENTS FROM CALLIANDRA HEMATOCEPHALA LEAVES AND THEIR BIOLOGICAL ACTIVITIES
}

\author{
BY \\ El-Sayed M. El-ghaly
}

FROM

Department of Pharmacognosy, Faculty of Pharmacy, Al-Azhar University, Cairo, Egypt

\begin{abstract}
Phytochemical investigation of Calliandra hematocephala (L`Her) Benth leaves (Leguminosae) resulted in isolation of $\beta$-sitosterol (1), Lupeol (2) and dodecanoic acid (3). The compounds were identified by chromatographic (TLC, PC) and spectroscopic analysis $\left({ }^{1} \mathrm{H}\right.$ NMR and ${ }^{13} \mathrm{C}$ NMR). This is the first report for isolation of compounds 2 and 3 from Calliandra hematocephala. All compounds (1-3) showed antifungal activity against Aspergillus fumigates, Penicillium italium and Geotricum candidum .They also showed antimicrobial activity against Staphylococcus aureus, Bacillis subtilis and Escherichia coli.
\end{abstract}

\section{INTRODUCTION}

Calliandra hematocephala (L`Her) Benth. (Family Leguminosae) is a perennial herb, widely distributed throughout tropical and subtropical America, some are present in India and West-Africa ${ }^{(1,2)}$. Leaves and barks are used in folk medicine as anti-tumor ${ }^{(3)}$, antioxidant $^{(3)}$, anti-cholinergic ${ }^{(4)}$, insecticide ${ }^{(5)}$, anti-malarial ${ }^{(6)}$ and astringent ${ }^{(7)}$. Triterpenes ${ }^{(8)}$, flavonoids ${ }^{(9)}$, pipecolic acids ${ }^{(10)}$ and glycolipids ${ }^{(11)}$ have been isolated from $C$.

hematocephala. The present paper describes the isolation and identification of three compounds from Calliandra hematocephala by nuclear magnetic resonance (NMR) and mass spectroscopy (ESI-MS). These compounds were evaluated for their antimicrobial $\operatorname{activities}^{(12)}$.

\section{MATERIAL AND METHODS}

\section{General experimental procedures}

${ }^{1} \mathrm{H}$ and ${ }^{13} \mathrm{C}$ NMR spectra were performed on a Bruker AMX at $400 \mathrm{MHZ}$ for ${ }^{1} \mathrm{H}$ and 100 for ${ }^{13} \mathrm{C}$. All NMR spectra were obtained in DMSO- $d_{6}$ and $\mathrm{CDCL}_{3}$ using TMS as an internal standard, the observed chemical shift ( $\delta$ values) are given in ppm, and coupling constants ( $J$ values) in hertz. TLC was performed on pre-coated plates with a silica gel layer, thickness of $200 \mathrm{~m}$. The ESIMS spectra were measured using a Bruker BioapexFTMS with electrospray ionization (ESI). Column chromatographic separation was performed on silica gel 60 (Si gel 60, Merck) and Sephadex LH-20 (Pharmacia). TLC was performed on precoated TLC plates with silica gel 60 F254 (0.2 mm, Merck). Developed chromatograms were visualized by spraying with $1 \%$ vanillin $-\mathrm{H}_{2} \mathrm{SO}_{4}$, followed by heating at $100{ }^{\circ} \mathrm{C}$ for $5 \mathrm{~min}$. 


\section{Plant material}

Calliandra hematocephala leaves were collected during the flowering stage (April 2011) from Orman garden at Giza. The plant was kindly identified by Engineer Badeia Hassan Aly Dewan, Consultant of Egyptian Flora, Agricultural Museum, Dokki, Giza, Egypt, and by Mrs. Terase Labib, Taxonomist of Orman Garden, Giza, Egypt.

\section{Extraction and isolation}

Air-dried powdered leaves of $C$. hematocephala $(500 \mathrm{~g})$ were subjected to successive extraction with methanol (3Lx4), where $35 \mathrm{~g}$ dry total extract were obtained. The total extract was subjected to VLC using silica gel for column and different organic solvents starting with petroleum ether, ethyl acetate , $n$-butanol and finally the column was washed out with distilled water to yield four fractions; petroleum ether fraction (4gm), ethyl acetate fraction $(5 \mathrm{gm}), n$-butanol fraction $(6 \mathrm{gm})$ and water fraction $(8 \mathrm{gm})$. The petroleum ether fraction (4gm) was subjected to CC using silica gel then finally subjected to Sephadex LH-20 eluted with methanol to yield six sub-fractions of A (200mg), B (350mg), C (500mg), D (450mg), E (100mg) and F (250mg). Sub-fraction D (450mg) was further chromatographed using Sephadex LH-20 and methanol to give two compounds 1 (15mg) and 2 (20mg). Sub-fraction A (200mg) was further purified using Silica gel column eluted with hexane:ethylacetate $(95: 10,90: 10$ and $85: 15$ ) followed by re-purification using Sephadex LH-20 and methanol to afford compound 3 (15mg).

Compound 1 [ $\boldsymbol{\beta}$-sitosterol]: White amorphous powder; gaves positive LiebermanBurchard test and negative Molish s test; $\mathrm{R}_{\mathrm{f}}: 0.46$ [TLC, Hexane:Ethyl acetate-80:20]; ${ }^{1} \mathrm{H}$ $\operatorname{NMR}\left(\mathrm{CDCl}_{3}, 400 \mathrm{MHz}\right) \delta 0.70(3 \mathrm{H}, \mathrm{s}, \mathrm{H}-18), 1.03(3 \mathrm{H}, \mathrm{s}, \mathrm{H}-19), 0.94(3 \mathrm{H}, \mathrm{d}, J=6 \mathrm{~Hz}, \mathrm{H}$ -21), $0.84(3 \mathrm{H}, \mathrm{d}, J=6 \mathrm{~Hz}, \mathrm{H}-26), 0.82(3 \mathrm{H}, \mathrm{d}, J=6.4 \mathrm{~Hz}, \mathrm{H}-27), 0.86(3 \mathrm{H}, \mathrm{t}, J=7.2 \mathrm{~Hz}, \mathrm{H}$ -29), 3.54 (1H, m, H-3), 5.37(1H, m, H-6); ${ }^{13} \mathrm{C} \mathrm{NMR}\left(\mathrm{CDCl}_{3}, 100 \mathrm{MHz}\right) \delta 11.87$ (C-18), 19.40 (C-19), 19.4 (C-21), 18.79 (C-26), 19.82 (C-27), 11.99 (C-29), 71.82 (C-3), 121.73 (C-6); EI-MS $m / z 414[\mathrm{M}]^{+}$.

Compound 2 [Lupeol]: White powder; melting point $213^{0} \mathrm{C} ;{ }^{1} \mathrm{H}$ NMR (DMSO-d $\mathrm{d}_{6}, 400$ MHz): $\delta 0.76,0.78,0.89,0.91,0.98,1.23,1.64($ each $3 \mathrm{H}$, each s, Me×7), $3.16(1 \mathrm{H}, d d, J$ $=5.4,10.6 \mathrm{~Hz}, \mathrm{H}-3), 4.54(1 \mathrm{H}, \mathrm{s}, \mathrm{H}-29 \mathrm{a}), 4.68(1 \mathrm{H}, \mathrm{s}, \mathrm{H}-29 \mathrm{~b}) ;{ }^{13} \mathrm{C}$ NMR $\left(\right.$ DMSO-d $_{6}, 100$ MHz): $\delta 150.6$ (C-20), 108.9 (C-29), 78.4 (C-3), 55.3 (C-5), 50.3 (C-9), 49.06 (C-18), 47.8 (C-19), 43.01 (C-17), 42.8 (C-14), 40.8 (C-8), 40.5 (C-22), 40.3 (C-13), 40.1 (C-4), 39.9 (C-1), 39.7 (C-10), 39.5 (C-16), 38.9 (C-7), 37.0 (C-21), 35.5 (C-23), 29.6 (C-15), 28.5 (C12), 27.1 (C-2), 20.8 (C-11), 18.4 (C-30), 18.2 (C-6), 18.0 (C-28), 16.8 (C-25), 16.4 (C-26), 16.0 (C-24), 15.1 (C-27); EIMS m/z: $426\left[\mathrm{M}^{+}\right.$.

Compound 3 [Dodecanoic acid]: White powder; ${ }^{1} \mathrm{H}$ NMR (DMSO- $\left.d_{6}, 400 \mathrm{MHz}\right): \delta 0.89$ (t, J=7.0 Hz, H -12), 2.12 (t, J= 7.5 Hz, H-2), 1.58 (m, H -3), 1.46 (m, H -11), 1.19 (m, H 4-H -9); ${ }^{13} \mathrm{C}$ NMR (DMSO- $d_{6} 100 \mathrm{MHz}$ ): 174.6 (C-1), 34.11(C-2), 25.1 (C-3), 29.26-29.47 (C-4-C-9), 31.92 (C-10), 22.64 (C-11) 14.09 (C-12); EIMS m/z: $201[\mathrm{M}+\mathrm{H}]^{+}$. 

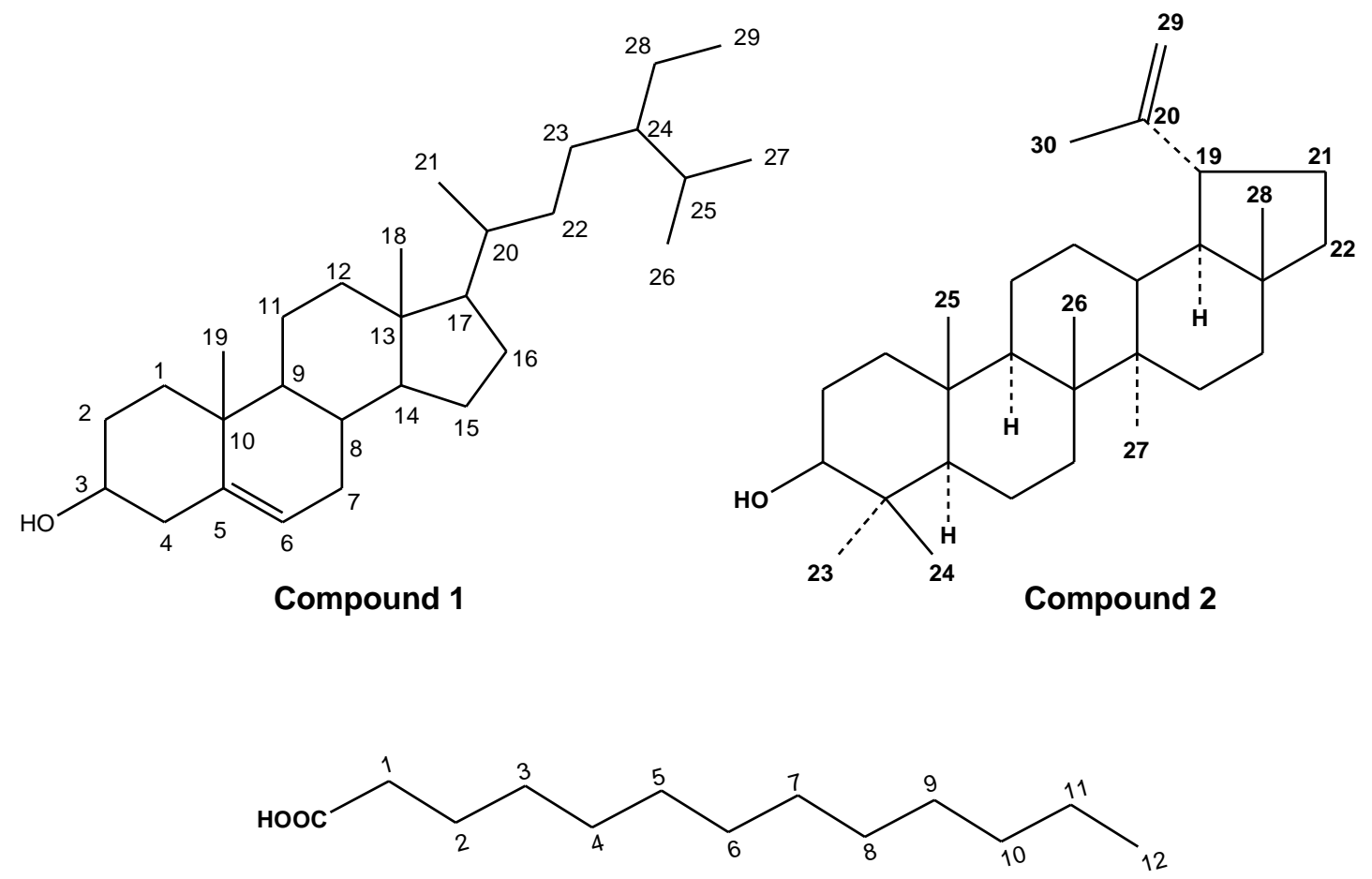

Compound 3

\section{Antimicrobial and antifungal activities of Calliandra haematocephala}

Antimicrobial activities of petroleum ether extract of Calliandra haemtocephala were investigated in vitro against different bacteria and fungi. The following bacterial strains were employed in the screening: Gram-positive bacteria; Staphylococcus aureus (RCMB 010028) and Bacillis subtilis (RCMB 010067), Gram-negative bacteria; Escherichia coli (RCMB 010052) and Pseudomonas aeruginosa (RCMB 010043). As fungal strains Aspergillus fumigates (RCMB 02568), Penicillium italicum (RCMB 03924), Geotricum candidum (RCMB 05097) and Candida albicans (RCMB 05031). Ampicillin, Gentamycin and Amphotericin B were used as reference drugs. The microbial species are environmental and clinically pathogenic microorganisms obtained from Regional Center for Mycology and Biotechnology antimicrobial unit (RCMB), Al-Azhar University.

\section{Determination of Antimicrobial Activity:}

Antimicrobial activities of petroleum ether extract of Calliandra haemtocephala were detected in vitro against the reference drug using the diffusion agar technique ${ }^{(12)}$. The results were recorded in table 1 .

\section{Investigation of lipoidal matter(Saponifiable and Unsaponifiable matters):}

The lipoidal matter obtained by extraction of $50 \mathrm{~g}$ of the air dried leaves of Calliandra haematocephala with n-hexane $(3 \times 300 \mathrm{ml})$ was evaporated in vacuo at $40^{\circ} \mathrm{c}$ to yield $(1 \mathrm{~g})$. This residue was kept for preparation of unsaponifiable matter (USM) and fatty acids (FA). 
Saponification:The n-hexane extract residue of both Calliandra haematocephala was saponified by refluxing with $15 \mathrm{ml}$ of $10 \%$ alcoholic $\mathrm{K} \mathrm{OH}$ for 10 hours. After distillation of the alcohol and dilution with $20 \mathrm{ml} \mathrm{H}_{2} \mathrm{O}$, the unsaponifiable matters of Calliandra haematocephala was extracted with ether $(3 \times 20 \mathrm{ml})$. The combined ether extracts were washed several times with distilled $\mathrm{H}_{2} \mathrm{O}$ till completely free from alkalinity, then dehydrated over anhydrous sodium sulphate and filtered. The residue left after evaporation of ether was subjected to GLC for identification of $\mathrm{HC}$ and sterol contents. The aqueous mother liquor was acidified with $2 \mathrm{ml}$ conc. $\mathrm{H}_{2} \mathrm{SO} 4$ to liberate corresponding free fatty acids. The liberated fatty acids were extracted with ether extract then dehydrated over anhydrous sodium sulphate ${ }^{13}$.

\section{GC/ MS analysis of lipoid matter.}

Samples were injected under the following conditions Helium was used as carrier gas at approximately $1 \mathrm{ml} / \mathrm{min}$., pulsed splitless mode. The solvent delay was $3 \mathrm{~min}$. and the injection size was $1.0 \mathrm{ul}$. The mass spectrophotometric detector was operated in electron impact ionization mode an ioning energy of 70 e.v. scanning from $\mathrm{m} / \mathrm{z} 50$ to 500 . the ion source temperature was $230{ }^{\circ} \mathrm{C}$ and the quadrupole temperature was $150^{\circ} \mathrm{C}$. The electron multiplier voltage (EM voltage) was maintained $1250 \mathrm{v}$ above auto tune. The instrument was manually tuned using perfluorotributyl amine (PFTBA). The GC temperature program was started at $60^{\circ} \mathrm{C}$ then elevated to $280^{\circ} \mathrm{C}$ at rate of $8{ }^{\circ} \mathrm{C} / \mathrm{min}$, and $10 \mathrm{~min}$. hold at $280^{\circ} \mathrm{C}$ the detector and injector temperature were set at $280^{\circ} \mathrm{C}$ and $250^{\circ} \mathrm{C}$, respectively. Wiley and Nist 05 mass spectral data base was used in the identification of the separated peaks.

\section{RESULTS and DISCUSSION}

Compound 1 [ $\boldsymbol{\beta}$-sitosterol]: Was obtained as white amorphous powder and gave positive Lieberman-Burchard test ${ }^{(14)}$ and negative Molishis test indicating sterol aglycone. The molecular formula was established as $\mathrm{C}_{29} \mathrm{H}_{50} \mathrm{O}$ from ${ }^{13} \mathrm{C}$ NMR data and EI-MS ion peak at $m / z 414[\mathrm{M}]]^{+}$. Its ${ }^{1} \mathrm{H}$ and ${ }^{13} \mathrm{C}$ NMR spectra showed six methyl signals at $\left[\delta_{\mathrm{H}} 0.70(3 \mathrm{H}, \mathrm{s}), \delta_{\mathrm{C}}\right.$ 11.87, Me-18], [ $\left.\delta_{\mathrm{H}} 1.03(3 \mathrm{H}, \mathrm{s}), \delta_{\mathrm{C}} 19.40, \mathrm{Me}-19\right]$ ], [ $\delta_{\mathrm{H}} 0.94(3 \mathrm{H}, \mathrm{d}, J=6 \mathrm{~Hz}), \delta_{\mathrm{C}} 19.4, \mathrm{Me}-$ 21], [ $\left.\delta_{\mathrm{H}} 0.84(3 \mathrm{H}, \mathrm{d}, J=6 \mathrm{~Hz}), \delta_{\mathrm{C}} 18.79, \mathrm{Me}-26\right],\left[\delta_{\mathrm{H}} 0.82(3 \mathrm{H}, \mathrm{d}, J=6.4 \mathrm{~Hz}), \delta_{\mathrm{C}} 19.82, \mathrm{Me}-\right.$ 27] and $\left[\delta_{\mathrm{H}} 0.86(3 \mathrm{H}, \mathrm{t}, J=7.2 \mathrm{~Hz}), \delta_{\mathrm{C}} 11.99, \mathrm{Me}-29\right]$, an oxygenated methine signal at $\left[\delta_{\mathrm{H}}\right.$ $\left.3.54(1 \mathrm{H}, \mathrm{m}), \delta_{\mathrm{C}} 71.82, \mathrm{CH}-3\right)$ and olefinic proton signal at $\delta_{\mathrm{H}} 5.37\left(1 \mathrm{H}, \mathrm{m}, \mathrm{H}-6, \delta_{\mathrm{C}} 121.73\right.$. The chemical shift value at $\delta_{\mathrm{C}} 71.82$ was attributed to the $\mathrm{C}-3$ which is indicated for the presence of $3 \beta$ hydroxyl group and confirmed that (1) was identified as $\beta$-sitosterol ${ }^{(15,16)}$.

Compound 2 [Lupeol]: Was obtained as white powder and gave positive test for steroids and triterpenes ${ }^{(14)}$. Its mass spectrum showed parent molecular ion peak $\left[\mathrm{M}^{+}\right]$at $\mathrm{m} / \mathrm{z}, 426$ which corresponds to the molecular formula $\mathrm{C}_{30} \mathrm{H}_{50} \mathrm{O}^{(14)}$. In the ${ }^{1} \mathrm{H}-\mathrm{NMR}$ spectrum of $2, \mathrm{H}-$ 3 proton appeared at $\delta 3.16(\mathrm{~J}=4.5, \mathrm{~m})$ and $\mathrm{H}-29$ olefinic proton showed a multiplet at $\delta 4.68$ and $\delta 4.54$. Seven methyl proton signals also appeared at $\delta 0.98,0.91,0.90,0.89$, $0.87,0.77$ and 0.76 (each $3 \mathrm{H}$, each $\mathrm{s}, \mathrm{CH}_{3}$ ). These assignments are in good agreement for the structure of lupeol ${ }^{(17,18)}$. 
Compound 3 [Dodecanoic acid]: Was obtained as white amorphous powder. Its mass spectrum showed a peak at $\mathrm{m} / \mathrm{z}, 201[\mathrm{M}+\mathrm{H}]^{+}$corresponding to the molecular formula $\mathrm{C}_{12} \mathrm{H}_{24} \mathrm{O}_{2}$. The ${ }^{1} \mathrm{H}$ NMR spectrum displayed a triplet at $\delta 0.89$ for the terminal methyl group. The triplet at $\delta 2.12$ was assigned to the methylene protons adjacent to carbonyl group. The ${ }^{13} \mathrm{C}$ NMR spectrum showed the signal at $\delta 174.6$ assigned for the carboxylic carbon and a signal at $\delta 14.09$ for terminal methyl carbon. Therefore the structure of compound 3 was concluded to be luaric acid (dodecanoic acid) ${ }^{(19,20)}$.

\section{Results of antimicrobial activity:}

The antibacterial and antifungal activities (MIC) of petroleum ether extract were measured in vitro against Gram-positive (Staphylococcus aureus and Bacillis subtilis) and Gramnegative (Escherichia coli and Pseudomonas aeruginosa) bacteria and fungi (Aspergillus fumigates, Penicillium italicum, Geotricum candidum and Candida albicans). The antibacterial activities were compared with those of Ampicillin and Gentamycin while the antifungal activities were compared with that of Amphotericin B. Table 1 showed that, the sample was active against Gram-positive bacteria more than Gram-negative bacteria. The sample has promising antimicrobial activity against Bacillis subtilis, Staphylococcus aureus, Geotricum candidum, Escherichia coli, Aspergillus fumigates and Penicillium italicum. The sample showed no activity against Candida albicans and Pseudomonas aeruginosa. The sample under investigation revealed minimum inhibitory concentration comparable to standard (Table 1). At concentration $3.9(\mu \mathrm{g} / \mathrm{ml})$ the sample has (MIC) antimicrobial activity against all tested microorganisms except for Candida albicans and Pseudomonas aeruginosa.

Table (1): Results of antimicrobial activity and MICS $(\mu \mathrm{g} / \mathrm{ml})$ of petroleum ether extract of Calliandra haematocephala

\begin{tabular}{|l|l|l|l|l|}
\hline \multirow{2}{*}{$\begin{array}{l}\text { Tested } \\
\text { microorganisms }\end{array}$} & \multicolumn{2}{|l|}{ Diameter of inhibition zone (mm) } & \multicolumn{2}{l|}{ MIC $(\mu \mathrm{g} / \mathrm{ml})$} \\
\cline { 2 - 5 } & Sample & ST. & Sample & ST. \\
\hline Fungi & & Amphotericin $B$ & & Amphotericin $B$ \\
\hline A. fumigates & $20.1 \pm 0.58$ & $27.3 \pm 0.10$ & 3.9 & 0.24 \\
\hline P. italicum & $19.9 \pm 0.44$ & $21.9 \pm 0.12$ & 3.9 & 0.98 \\
\hline C. albicans & NA & $19.8 \pm 0.20$ & NA & 3.9 \\
\hline G. candidum & $22.3 \pm 0.22$ & $28.7 \pm 0.22$ & 0.98 & 0.06 \\
\hline G + ve bacteria & & Ampicilin & & Ampicilin \\
\hline S. aureus & $22.8 \pm 0.22$ & $27.4 \pm 0.18$ & 0.49 & 0.12 \\
\hline
\end{tabular}




\begin{tabular}{|l|l|l|l|l|}
\hline B. subtilis & $24.8 \pm 0.22$ & $32.4 \pm 0.10$ & 0.12 & 0.007 \\
\hline G - ve bacteria & & Gentamycin & & Gentamycin \\
\hline P. aeruginosa & NA & $17.3 \pm 0.15$ & NA & 7.81 \\
\hline E. coli & $20.3 \pm 0.58$ & $22.3 \pm 0.18$ & 3.9 & 0.49 \\
\hline
\end{tabular}

Well diameter: $6.0 \mathrm{~mm} \ldots . . . .(100 \mu \mathrm{l}$ was tested), Sample concentration $(10 \mathrm{mg} / \mathrm{ml})$,

NA: No activity,

Data are expressed in the form of mean \pm Standard deviation.

\section{Results of GC/ MS analysis of lipoid matter:}

The results of GC/ MS analysis of lipoid matter of Calliandra haematocephala revealed that it contains decane, undecane, dodecane, methylhexadecanoate, phytol, phthalate, stigmasterol, $\beta$-sitosterol and lupeol with different ranges of concentration. Dodecane and phytol were represented the major components, while stigmasterol and decane were the lowest ones (Table 2).

Table 2: GC/MS analysis of unsaponifiable matter of C. haematocephala

\begin{tabular}{|c|c|c|c|c|c|}
\hline \multirow[t]{3}{*}{$\mathrm{NO}$} & \multicolumn{5}{|c|}{ GC/MS analysis } \\
\hline & GC & \multicolumn{4}{|l|}{ MS } \\
\hline & $\mathrm{R} \mathrm{t}$ & $\%$ & Mol. Wt. & B .P & Name \\
\hline 1 & 3.91 & $0.02 \%$ & 112 & 83 & Ethyl cyclohexane \\
\hline 2 & 4.90 & $0.15 \%$ & 126 & 97 & $\begin{array}{l}\text { Ethyl- } \\
\text { methylcyclohexane }\end{array}$ \\
\hline 3 & 5.10 & $0.25 \%$ & 128 & 57 & Nonane \\
\hline 4 & 5.60 & $0.04 \%$ & 114 & 57 & Octane \\
\hline 5 & 7.18 & $5.26 \%$ & 142 & 57 & Decane \\
\hline 6 & 8.30 & $0.14 \%$ & 154 & 55 & Cyclodecanone \\
\hline 7 & 9.28 & $6.9 \%$ & 156 & 57 & Undecane \\
\hline 8 & 9.97 & $0.65 \%$ & 154 & 83 & Pentylcyclohexane \\
\hline 9 & 10.52 & $2.34 \%$ & 310 & 43 & Docosane \\
\hline 10 & 11.23 & $8.57 \%$ & 170 & 57 & Dodecane \\
\hline 11 & 13.00 & $0.23 \%$ & 184 & 57 & Tridecane \\
\hline
\end{tabular}




\begin{tabular}{|c|c|c|c|c|c|}
\hline 12 & 14.57 & $0.30 \%$ & 198 & 55 & Tetradecane \\
\hline 13 & 16.27 & $0.05 \%$ & 212 & 57 & Pentadecane \\
\hline 14 & 17.77 & $0.12 \%$ & 226 & 57 & Hexadecane \\
\hline 15 & 18.89 & $0.04 \%$ & 196 & 55 & Cyclotetradecane \\
\hline 16 & 19.20 & $0.12 \%$ & 240 & 57 & Heptadecane \\
\hline 17 & 19.60 & $0.042 \%$ & 196 & 69 & Tetradecene \\
\hline 18 & 20.54 & $0.82 \%$ & 254 & 57 & Octadecane \\
\hline 19 & 20.67 & $0.15 \%$ & 282 & 57 & Eicos ane \\
\hline 20 & 21.07 & $0.21 \%$ & 278 & 68 & Neophytadiene \\
\hline 21 & 21.81 & $0.74 \%$ & 268 & 57 & Nonadecane \\
\hline 22 & 22.17 & $8.36 \%$ & 270 & 74 & Methyl hexadecanoate \\
\hline 23 & 23.37 & $0.14 \%$ & 284 & 74 & Methyl heptadecanoate \\
\hline 24 & 24.20 & $3.80 \%$ & 294 & 67 & Methyl octdecanoate \\
\hline 25 & 24.46 & $31.7 \%$ & 296 & 71 & Phytol \\
\hline 26 & 28.38 & $3.02 \%$ & 308 & 57 & Eicosanol \\
\hline 27 & 38.50 & $4.04 \%$ & 412 & 55 & Stigmaterol \\
\hline 28 & 39.86 & $5.40 \%$ & 414 & 414 & B- sitosterol \\
\hline 29 & 41.99 & $13.12 \%$ & 426 & 207 & Lupeol \\
\hline
\end{tabular}

GC/MS of saponifiable fraction showed that $C$. haematocephala contains Hexadecanoic acid, octadecanoic acid, Phthalic acid and octadecatrienoic acid. Hexadecanoic acid and octadecanoic acid were represented the major components, while Phthalic acid and octadecatrienoic acid were the lowest ones (Table 3).

Table 3: GC/MS analysis of saponifiable matter of C. haematocephala

\begin{tabular}{|l|l|l|l|l|l|}
\hline \multirow{2}{*}{ NO } & \multicolumn{4}{|l|}{ GC/MS analysis } \\
\cline { 2 - 6 } & GC & MS & Mol. Wt . & B .P & Name \\
\hline & R t & $\%$ & . & &
\end{tabular}




\begin{tabular}{|c|c|c|c|c|c|}
\hline 1 & 17.31 & $0.71 \%$ & 200 & 73 & Dodecanoic acid \\
\hline 2 & 17.71 & $0.083 \%$ & 228 & 88 & $\begin{array}{l}\text { Dodecanoic acid } \\
\text { methyl ester }\end{array}$ \\
\hline 3 & 20.09 & $1.18 \%$ & 228 & 73 & Tetradecanoic acid \\
\hline 4 & 20.47 & $0.12 \%$ & 256 & 88 & $\begin{array}{l}\text { Tetradecanoic ethyl } \\
\text { ester }\end{array}$ \\
\hline 5 & 21.38 & $0.82 \%$ & 242 & 73 & Pentadecanoic acid \\
\hline 6 & 22.16 & $2.28 \%$ & 270 & 74 & $\begin{array}{l}\text { Hexadecanoic } \\
\text { acid,methylester }\end{array}$ \\
\hline 7 & 22.88 & $36.89 \%$ & 256 & 73 & n-Hexadecanoic acid \\
\hline 8 & 23.85 & $0.76 \%$ & 270 & 73 & Heptadecanoic acid \\
\hline 9 & 24.20 & $1.15 \%$ & 294 & 67 & $\begin{array}{l}\text { Octadecadienoic } \\
\text { methyl ester }\end{array}$ \\
\hline 10 & 24.28 & $1.45 \%$ & 292 & 79 & Octadecatrienoic acid \\
\hline 11 & 24.91 & $22.76 \%$ & 264 & 57 & Octadecadienoic acid \\
\hline 12 & 27.07 & $2.15 \%$ & 312 & 88 & $\begin{array}{l}\text { Octdecanoic acid } \\
\text { methyl ester }\end{array}$ \\
\hline 13 & 29.02 & $15.21 \%$ & 279 & 149 & Phthalic acid \\
\hline
\end{tabular}

\section{REFERENCES}

Allen, O. N. and Allen E. K. (1981) "The Leguminosae" $1^{\text {st }}$ Edn. The University of Wicsonin Press, USA, pp. 237-238, 125-126,.

Bailey, L. H., (1924) "Manual of Cultivated Plants", The Macmillan Comp. New York, pp. 592,.

Moharram, F. A., Marzouk, M. S. A., Ibrahim, M. T.and Mabry, T. J. (2006), Natural Product Research, 20 (10), 927-934,.

Akah, P. A. and Nwaiwu, J. I., (1998)J. Ethnopharmacol. 22 (2), 205-210,

Aguwa, C. N. and Lawal, A. M., (1998) J. Ethnopharmacol. 22 (1), 63-71,.

Romeo, J. T. (1984), Biochemical Systematics and Ecology, Vol. 12, No. 3, pp. 293-297,.

Eisa, M. M., Almagboul, A. Z. (2000), and Omer, M. E. A., Fitotrapia, 71, 324-327,.

Takeda, T., Nakamura, T. and Takashima, S. (1993), Chem. Pharm. Bull. 41 (12), 2132- 2137,. 
Harborne, J. B., (1999) "The flavonoids Advanced in Research since 1986" Chempman \& Hall., London, New York, Tokyo, 499-514,.

Bleecker, A. B. and Romeo, J. T. (1983), Phytochemistry, 22 (4), 1025-1026,.

Hans-Walter, H., (1999) “Plant Biochemistry and Molecular Biology”, Oxford University Press, UK. PP 317-351,.

Finn, R. K.(1959) "Theory of agar diffusion methods for bioassay. Anal Chem ;1: 975 $-7$.

El-said, F. M. and Ammer, M. M. (1965) "Oils, Fats, Waxes and Surfactants" Anglo Egyptian Book shop (Cairo), P. 130

Harborne, J. B. (1998), "Phytochemical Methods: A Guide to Modern Techniques of Plant Analysis" 3rd Edn., chapman and Hall: London. ISBN: 0-412-57270-2, 302,.

Habib, M. R., Nikkon, F., Rahman, M. E., and Karim, M. R. (2007), Pak. J. Biol. Sci. 10: 4174-4176,.

Pateh, U. U., Haruna, A. K., Garba, M., Iliya, I., Sule, I. M., Abubakar, M. S. and Ambi, A. A. (2009), Nigerian journal of Pharmaceutical Sciences. 7(1): 19-25,.

Imam, S., Azhar, I., Hasan, M. M., Ali, M. S. and Ahmed, S. W., (2007) Pak. J. Pharm. Sci., 20: 125-127,.

Jain, P. S. and Bari, S. B. (2010), Asian Journal of Plant Sciences, 9: 163-167,.

Jian-Qiao Gua, b, C. Mark Epplerc, Gloria Montenegrod, Scott D. Timminsc, and Barbara N. (2005) Timmermanna, Naturforsch. 60 c, 527Đ533; received February $1,2005$.

Thakur A, Jain V, Hingorani L, Laddha K S.(2009): Phytochemical Studies on Cissus quadrangularis Linn. Phog Res ,1:213-5. 


\section{مركبات من اوراق نبات كاليندرا هيماتوسيفلا وفاعليتها الحيوية}

$$
\text { للسيد الدكتور }
$$

السيد محمد السيد الغالى

قسم العقاقير - كلية الصيدلة - بنين بالقاهرة - جامعة الاز هر

تم فصل ثلاث مركبات من خلاصة الأيثير البترولى، مركب منهم من مشتقات استيرو لات وهو مركب بيتاسيتوستيرول

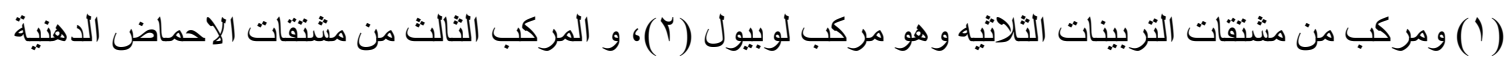

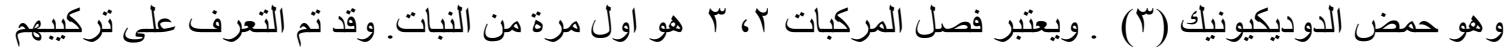

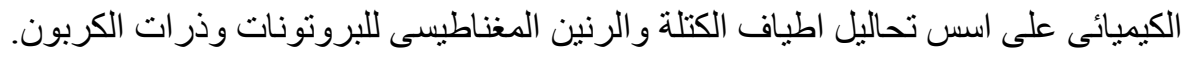

وقد وجد ان Diffusion Agar Method كما تم در اسة الفاعلية المضادة للميكروبات لهذه المركبات باستخدام خلاصة الأيثير البترولى لها تا ثير قوى كعامل مضاد للميكروبات. 